\title{
WINTERING CHIRONOMIDS MINE OXYGEN
}

\author{
MURRAY K. GINGRAS,* STEFAN V. LALOND, LARRY AMSKOLD, and KURT O. KONHAUSER \\ Department of Earth and Atmospheric Sciences, 1-26 Earth Science Building, University of Alberta, Edmonton, Alberta, T6G 2E3 Canada \\ e-mail: mgingras@ualberta.ca
}

\begin{abstract}
Seasonally sampled cores of burrowed sediment containing chironomid larvae were collected from Cooking Lake, Alberta, and analyzed to (1) assess and establish the typical burrowing behavior and burrow architecture of chironomid larvae; (2) record micrometer-scale geochemical profiles of $\mathrm{O}_{2}, \mathrm{H}_{2} \mathrm{~S}$, and $\mathrm{pH}$ in the uppermost sedimentary layers throughout a seasonal cycle; and (3) link changing geochemical conditions to changing burrowing behaviors. We observed that the larvae lived in soft, water-saturated sediment, maintained by open burrows accreted by the animal's mucous. Chironomid-larvae burrows were small and Y-shaped (e.g., Polykladichnus-like) or Y-shaped with basal branches (Thalassinoides-like) and were $20 \mathrm{~cm}$ deep. The larvae moved up and down from the oxygenated zone ("sounding" behavior) to exploit food in suboxic and anoxic sediment. Geochemical analyses showed that $\mathrm{H}_{2} \mathrm{~S}$ was present in the pore waters to within $1.5 \mathrm{~mm}$ of the sediment-water interface during the summer, when lake-bottom algae and cyanobacteria generated sufficient $\mathrm{O}_{2}$ to drive the oxic-anoxic redoxcline into the sediment. In the winter, the $\mathrm{H}_{2} \mathrm{~S}$ front extended upward into the water column owing to the cessation of algal and cyanobacterial activity. The prevalence of $\mathrm{H}_{2} \mathrm{~S}$ results from a combination of high-dissolved-sulfate concentrations in the lake and the abundance of microbial biomass that fuels an active subsurface population of sulfate-reducing bacteria. Interestingly, burrowing behavior was not linked to seasonal changes in the sediment chemistry. This is in part due to the ability of chironomid larvae to exploit oxygen islands in the sediment: in the winter, the chironomid larvae harvest their oxygen from the uppermost photosynthetic layer in otherwise $\mathrm{O}_{2}$-impoverished sediments.
\end{abstract}

\section{INTRODUCTION}

This paper considers the significance and ecology of chironomid larvae and their burrows studied in Cooking Lake, Alberta, Canada (Fig. 1). These animals were chosen for study because they reside in Polykladichnus-like and small Thalassinoides-like burrows that do not conform to typical (albeit far-older) biogenic structures known from fossil examples of the Mermia Ichnofacies. Also, the strong seasonality of Cooking Lake should provide striking ichnological contrast with changing conditions. At Cooking Lake, chironomid larvae are the dominant bioturbators in water deeper than $1 \mathrm{~m}$.

Freshwater trace-fossil assemblages are referred commonly to as the Mermia Ichnofacies. Trace fossils of the Mermia Ichnofacies are dominated by straight, crudely meanderform, and, very rarely, eurhythmically meanderform, loosely spiraling trails and various Repichnia (Buatois and Mangano, 2002). Such trace fossils can largely be attributed to the activities of insect larvae. Oligochaetes, amphipods, mollusks, and ostracodes, however, definitely contribute to a freshwater ichnological signature (e.g., Miller, 1984; Hasiotis, 2004, 2005). In spite of their abundance in modern temperate lakes, vertical and penetrative trace fossils are rarely reported from lacustrine deposits, and therefore such burrows are not widely rec-

* Corresponding author.

Copyright (c) 2007, SEPM (Society for Sedimentary Geology) ognized as an important component of freshwater ichnocoenoses. This oversight is rationalized: easily compacted, organic-rich lake sediments present a taphonomic barrier that strongly discriminates against the preservation of vertical traces. Biological studies, however, show that vertical biogenic structures are an important component of nutrient cycling in lake sediments, and understanding their ecology should contribute to a better understanding of ancient lake sediments (Svenson and Leonardson, 1996; Covich et al. 1999).

The family Chironomidae (nonbiting midges) comprises dipteran insects found in all geographical regions of the world (Sæther, 2000). The immature stages of most chironomids occur in freshwater; some tolerate lower oligohaline salinities. As a result of their broad distribution and because their larval head capsules preserve well as subfossils (Hofmann, 1971, 1986), chironomids are used extensively for lake classification (Brinkhurst, 1974). Thus, at least for studies of recent and Neogene paleoecology, the recognition of chironomid burrows or subfossils can likely enhance assessments of past environmental conditions (for a discussion of chironomid subfossils, see Warwick, 1980; Walker, 1987, 1995; and Velle et al., 2005).

We consider three factors pertaining to chironomid larvae bioturbation: (1) establishing the morphology and behavior of chironomid burrows, (2) establishing the geochemical stratigraphy of chironomid-burrowed sediment in different seasons, and (3) linking the evolving geochemistry to chironomid burrowing behavior. Few studies have been conducted that specifically correspond to chironomid burrowing behavior or burrow architecture (Miller, 1984, however, recognizes their significance). In contrast, it is well accepted that the effect of bioturbation is considerable with respect to geochemical models. This is because bioturbation alters the flux of solutes and dissolved gases, and it modifies the concentration, reactivity, and distribution of sedimentary organic matter (Berner and Westrich, 1985; Boudreau and Marinelli, 1994). Only a few studies relating lacustrine diagenesis to bioturbation activity have been conducted (Graneali, 1979; Fukuhara and Sakamoto, 1987; Andersen and Jensen, 1991). These studies show that such small organisms as chironomid larvae can stimulate microbial activity and enhance the decomposition of organic matter in sediments (Hansen et al., 1998). Because of a lack of spatially high-resolution, in situ geochemical data, linking burrowing behavior to sediment and bottom-water chemistry has not been addressed previously in the existing literature. Indeed, methodological difficulties have certainly hampered efforts to establish sediment chemostratigraphy at the detail needed to consider links between bioturbation and colonized sediment. The successful development of microsensors now permits detailed measurements of many geochemical parameters, including $\mathrm{pH}$, redox potential, flow velocity, diffusivity, and aqueous concentrations of sulfide, oxygen, and nitrate. This study benefits from the relatively new technology and shows its potential for neoichnological studies.

\section{STUDY AREA}

Cooking Lake is a located in north-central Alberta, about $25 \mathrm{~km}$ east of Edmonton (Fig. 1). The lake is near the southern edge of the North American boreal forest, and it is in a high-temperate climate. Cooking Lake has a surface area of about $35 \mathrm{~km}^{2}$ (planimeter estimate from map). 


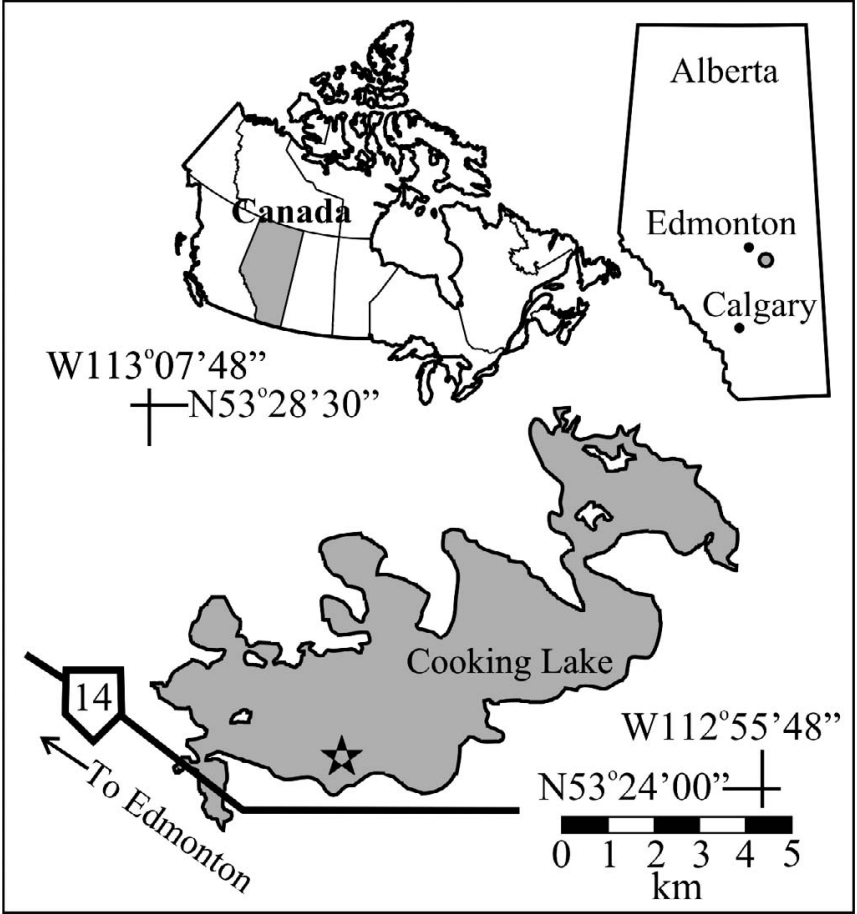

FIGURE 1-Location map of Cooking Lake, Alberta. In the upper frame, Alberta is highlighted within Canada. The general location of sampling is indicated by a gray circle within the outline of Alberta (upper right). The lower map shows Cooking Lake in detail with the best access road numbered.

The lake's maximum depth is about $4.5 \mathrm{~m}$, and the mean depth is nearly $2 \mathrm{~m}$. Cooking Lake's drainage basin area is about four times larger than the lake area (Mitchell and Prepas, 1990). There is an outlet creek on the eastern end of the lake, but it only flows when water levels are very high; water was last known to flow away from Cooking Lake during the 1950s (Mitchell and Prepas, 1990). Recent sediment in Cooking Lake is dominantly fine grained (silt) and algal rich. Older underlying sediments are more commonly sandy to cobbly as the lake sits in part on moraine and outwash derived from the most recent glaciation of central Alberta.

Between October and April the lake surface is frozen to a depth of 50 $\mathrm{cm}$. This interrupts the exchange of $\mathrm{O}_{2}$ between the lake and the atmosphere. Organics in the lake consume dissolved $\mathrm{O}_{2}$, and the lake is dysoxic to anoxic from December until April.

\section{METHODS}

Collection of burrowed sediment occurred in August and December 2004 and February and April 2005. The December and February samples were retrieved with a sediment core through a bored hole in the ice. The other samples were cored from a small boat. All of the samples were collected during daylight hours approximately $400 \mathrm{~m}$ from the southern shoreline (Fig 1). The cores were extracted using a 6-cm-diameter by 50cm-long (clear-plastic), weighted drop core equipped with a spring-loaded, operator-triggered trap (Glew Corer; see Glew, 1989). Some cores were used to observe directly the burrows and extract the animals. Observations of the burrow morphology were made directly from the core. During the August trip, skin diving was done to observe the lake bottom. Two cores were recovered each sampling day, sealed immediately without any gas headspace in the core tube, and transported to the University of Alberta for microsensor analysis. The return trip to Edmonton takes about 1 hour. To avoid disruption and resuspension, the sealed sediment- and water-filled core tubes were held upright by hand for the duration of transport.

In the lab, sediment cores were unsealed, and excess lake water was carefully removed by vacuum siphon, so as to not disturb the sediment



FIGURE 2-Schematic of the microsensor apparatus with core in place. The microsensor is adjusted incrementally with the micromanipulator, which permits lowering of the needlelike sensor in $\mu \mathrm{m}$-scale increments. In this way, the sensor tracks gas content as it is lowered through the water and into the sediment.

water interface, until approximately $3 \mathrm{~cm}$ of lake water remained in the core tube above the sediment. A core extruder was used to advance the core tube contents (sediment underlying lake water) to within 1-2 cm of the top of the core tube, and microsensors were extended directly into the core tubes using a Unisense MM33-2 micromanipulator (Fig. 2). Oxygen, hydrogen sulfide and $\mathrm{pH}$ profiles were taken in undisturbed (unburrowed) sediment using Unisense OX50, H2S50, and PH50 microelectrodes with $50 \mu \mathrm{m}$ tips. The microsensor assembly was connected to the Unisense PA2000 picoammeter linked to a PC data-acquisition system. Immediately prior to analysis, the oxygen electrode was zeroed in a 0.1 $\mathrm{M}$ ascorbic acid solution and referenced to atmospheric oxygen. The sulfide electrode was calibrated using anoxic solutions prepared with known concentrations of sodium sulfide and phosphate buffered to $\mathrm{pH}=7$. Solute concentrations were measured at $500 \mu \mathrm{m}$ intervals. Solute profiles were taken from the sediment surface to $1.5-2.5 \mathrm{~cm}$ depth, once solute concentrations or $\mathrm{pH}$ leveled.

Sampled chironomid larvae were placed in a thin-walled aquarium to make detailed observations of their burrowing behavior. Thin-walled aquaria were seeded with lake sediment and fed with lake water to limit the habitat shock suffered by transplanted animals.

\section{RESULTS}

Chironomid larvae were the dominant burrowing animals observed and extracted from the sediment cores; most likely belong to Chironomus sp. (Fig. 3A,C). As many as 20 individuals were sampled from the $30 \mathrm{~cm}^{2}$ area of the core, which is equivalent to about 6,000 individuals per $\mathrm{m}^{2}$ (Fig. 3B). Subsequent diving confirmed the high-population densities. All sampling expeditions revealed no notable seasonal change in the style of bioturbation. By volume, the sediment was composed of about $80 \%$ algal and cyanobacterial biomass and about $20 \%$ silt. The sediment was very soft and thus easily disturbed. It commonly became cohesive at 20-40 $\mathrm{cm}$ depth; this usually represented the contact with glacially derived sediment. 

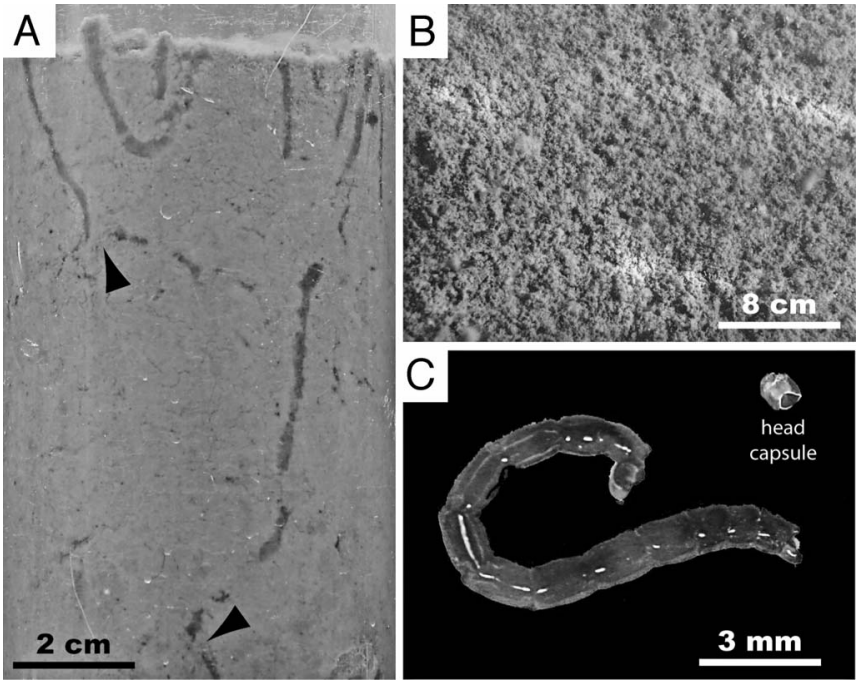

FIGURE 3-Chironomid larvae burrows and Chironomus collected from Cooking Lake. A) Glew Core with burrows constructed by chironomid larvae; basal branches are indicated with arrows. B) Lake-bottom surface modified by intense chironomid larvae activity, lending the tufted appearance. C) Close-up of Chironomus sp. with close-up of head capsule.

\section{Bioturbation}

In spite of the very soft and water-saturated sediment conditions, chironomid larvae manage to maintain open burrows. Burrows were generally $1-3 \mathrm{~mm}$ in diameter, tubular, and extended to a depth of approximately $20 \mathrm{~cm}$. The burrows had an open aperture to the sediment-water interface; the aperture normally had a chimney extending the burrow as much as $3 \mathrm{~mm}$ above the sediment-water interface. The subapertural architecture comprised one of the following (Fig. 4): (1) a U- or Y-shaped tube with a basal tube that descended obliquely to a depth of 10-20 cm (e.g., Arenicolites or Polykladichnus-like), (2) a Y-shape with a basal tube that descended obliquely to a depth of $10-20 \mathrm{~cm}$ with one or more basal branches (e.g., Thalassinoides-like), or (3) a singular tube that descended to the same depth as the other forms with one or more basal branches (Thalassinoides-like).

Although no turning chambers were observed, larvae were observed to move forward and backward in their burrows. Chironomid larvae also showed excellent agility and were able to turn around within the confines of the tubes. The burrows observed were formed by intrusion of the sediment, which slightly compacted the burrow margins within the organic-rich sediment. Close scrutiny did not reveal obvious annular contractions, and we saw that much of the burrow formation was due to arcuate flexing of the larval abdomen and thorax. The chironomids further maintained burrow-wall stabilization with mucous, derived likely from the mouthparts of the larvae.

\section{Geochemistry}

Geochemical profiles were measured in August and December 2004 and February and April 2005. In August 2004, the lake was open and well mixed owing to a north wind gusting to $20 \mathrm{~km} / \mathrm{hr}$ that persisted through much of the day. The lake-bottom community was in good health. All of the ensuing geochemical samples were obtained through winter ice. The ice was present for the entire winter and completely covered the lake, so above-ice conditions did not directly influence the lake bottom. By April, localized nearshore open water (shore-lead) was present along the north shore of the lake. Chironomid larvae were present throughout the study; they were observed to move more slowly when the lake waters were coldest.

Hydrogen sulfide, $\mathrm{pH}$, and dissolved oxygen were measured from the core extracted during each sampling stage. The $\mathrm{H}_{2} \mathrm{~S}$ concentrations (Fig. $5 \mathrm{~A}$ ) were lowest during August 2004. At that time $\mathrm{H}_{2} \mathrm{~S}$ was not detected to a depth of $-1.5 \mathrm{~mm}$. Below $-1.5 \mathrm{~mm}, \mathrm{H}_{2} \mathrm{~S}$ increased slowly and gradually to a peak of $335 \mu \mathrm{M}$ (micromole per liter) at $-15 \mathrm{~mm}$. In December, the first detectable $\mathrm{H}_{2} \mathrm{~S}$ occurred at approximately the same depth as in August, but $\mathrm{H}_{2} \mathrm{~S}$ concentrations rose sharply and continuously to $10,000 \mu \mathrm{M}$ near $-11 \mathrm{~mm}$. Below $-11 \mathrm{~mm}$, the electrode became saturated. A similar pattern was observed in February, but the initial detection of $\mathrm{H}_{2} \mathrm{~S}$ (about $300 \mu \mathrm{M}$ ) was in the water $13 \mathrm{~mm}$ above the lake bottom. In the sediment $\mathrm{H}_{2} \mathrm{~S}$ continuously rose to more than 11,000 $\mu \mathrm{M}$ at $-8 \mathrm{~mm}$; at that depth the electrode became saturated. The April core had a comparatively attenuated $\mathrm{H}_{2} \mathrm{~S}$ profile with two peak measurements of 500 and $2,900 \mu \mathrm{M}$ at -5 and $-20 \mathrm{~mm}$, respectively.

The $\mathrm{pH}$ profiles (Fig. 5B) are inverse crudely to the $\mathrm{H}_{2} \mathrm{~S}$ profiles (Fig. $5 \mathrm{~A})$. In general, the $\mathrm{pH}$ decreases with depth and decreases with duration of ice cover. The highest $\mathrm{pH}$ was recorded in August-9.5 at the sediment-water interface to 8.6 at $-16 \mathrm{~mm}$. In December, $\mathrm{pH}$ was 8.5 in the bottom water and to a depth of $-6 \mathrm{~mm}$. The $\mathrm{pH}$ dropped abruptly to 7.8 at $-10.5 \mathrm{~mm}$ and remained so deeper in the sediment. Lake-water $\mathrm{pH}$ was 8.4 in February, and $\mathrm{pH}$ dropped continuously in the sediment to 7.4 at $-18 \mathrm{~mm}$. April $\mathrm{pH}$ is lower in the bottom water (8.1) and it dropped

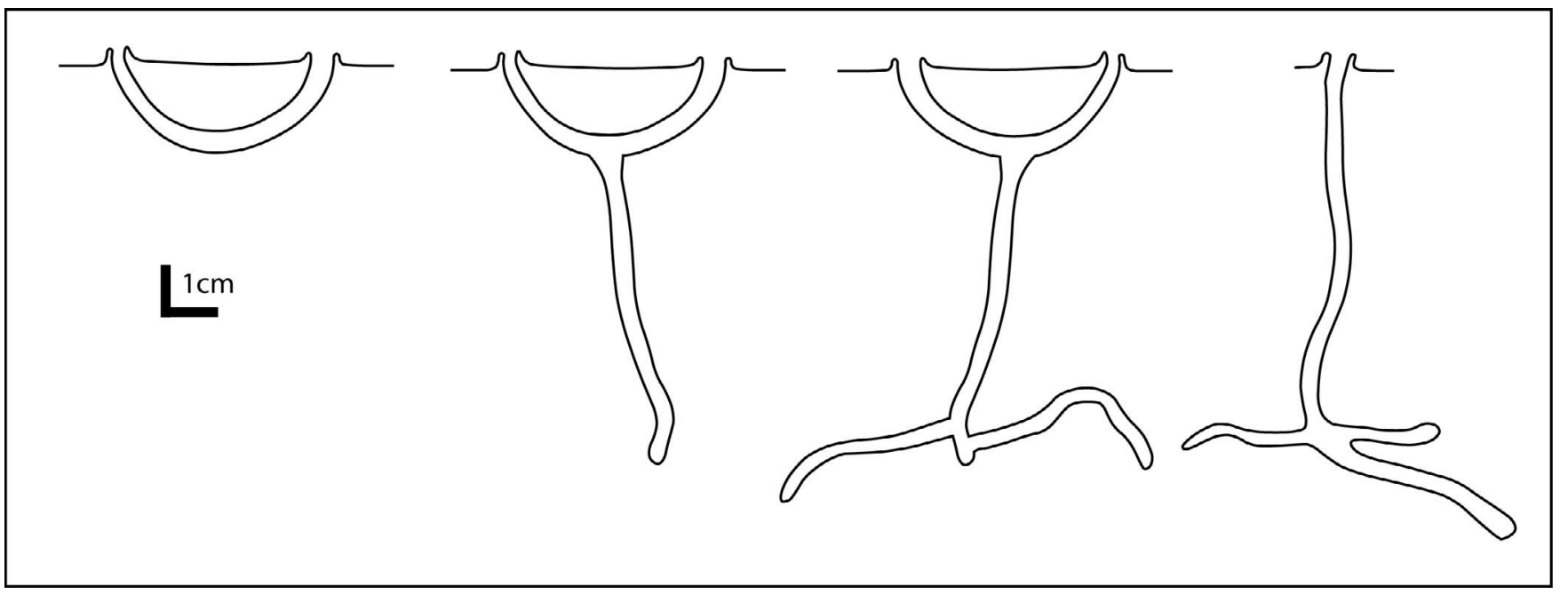

FIGURE 4-General form of burrows of chironomid larvae at Cooking Lake, Alberta. From left are shown Arenicolites-, Polykladichnus-, and Thalassinoides-like burrows (Thalassinoides are the two rightmost). Scale indicated is approximately $1-2 \mathrm{~cm}$. 

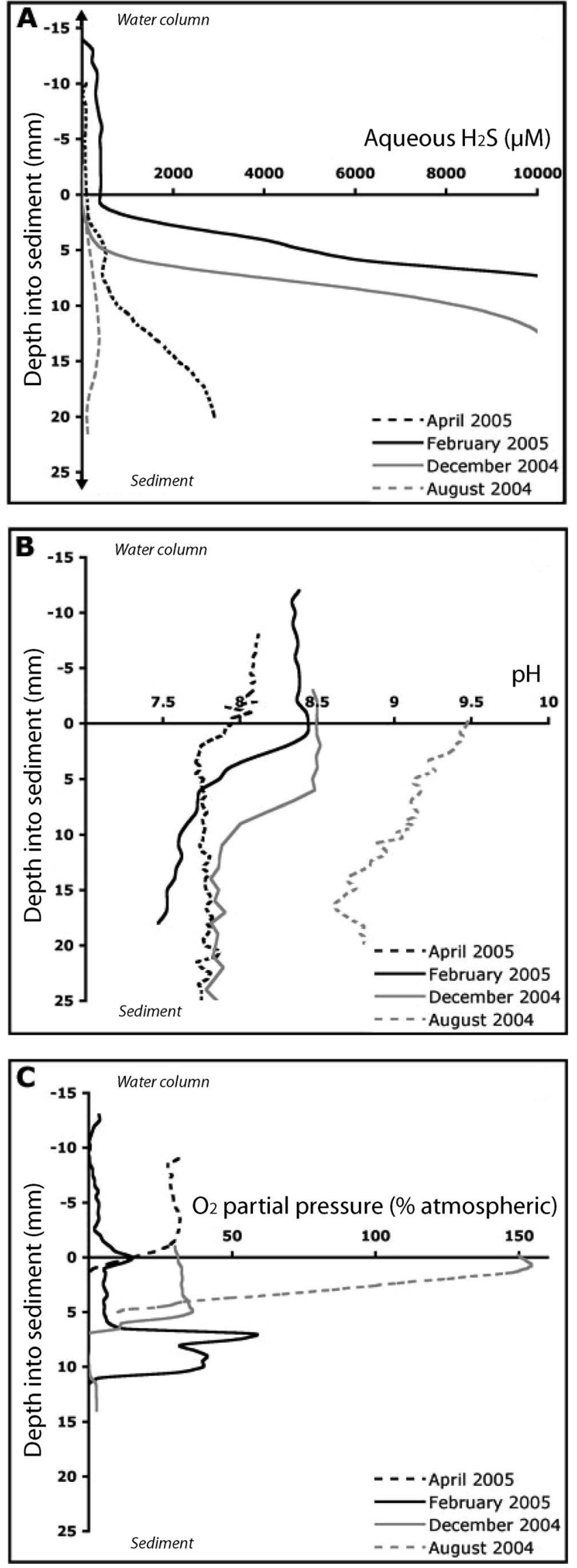

to 7.7 in the sediment, leveling out at a somewhat higher $\mathrm{pH}$ than in February.

In general, dissolved oxygen (Fig. 5C) decreased from August to February and increased in April. In August, dissolved oxygen at the sediment-water interface was at $155 \%$ atm of typical atmospheric levels (owing to $\mathrm{O}_{2}$ production by the organic mat). This rose slightly in the sediment to about $155 \%$ atm at $-2 \mathrm{~mm}$. Below $-2 \mathrm{~mm}, \mathrm{O}_{2}$ decreased to less than $10 \%$ atm near $-5 \mathrm{~mm}$. By December, $\mathrm{O}_{2}$ levels had dropped substantially. Measured values near $50 \%$ atm were observed from the water and sediment to a depth of $-5 \mathrm{~mm}$. Below that depth, $\mathrm{O}_{2}$ decreased to near zero. Lake-water oxygen was very low in February; the water was nearly anoxic (i.e., dissolved $\mathrm{O}_{2}$ zero), but two oxygen spikes occur in the sediment. The first $\mathrm{O}_{2}$ high of $16 \%$ atm was found at the sediment water interface; the second spike of 10\%-60\% atm was found at $-6 \mathrm{~mm}$ and represents the accidental intersection of the sharp sensor tip with the abdomen of a chironomid larvae.

\section{INTERPRETATION AND DISCUSSION}

\section{Burrowing Behavior}

At Cooking Lake, chironomid larvae dwell in organic-rich sediment. The burrows are ephemeral but stayed open for at least 2 days in thinwalled aquaria. The animal showed little propensity to enter compacted sediment, but this may be specific to the Cooking Lake locale or to the species of chironomid. Once abandoned, the burrows healed quickly, and their preservation potential is clearly low in soft sediments.

In February, the only available source of oxygen was at the sedimentwater interface. The water column was anoxic, as was the substrate (Fig. $5 \mathrm{C})$, yet the larvae were surprisingly active. They were observed well below the sediment-water interface $(0 \mathrm{~mm}$ on Fig. $5 \mathrm{C})$ and consistently rose back up to the thin, photosynthetic (oxygenated) zone. The burrowing depth of the larvae is surprisingly deep. The animals were observed commonly to a depth of $20 \mathrm{~cm}$. One chironomid larva was observed exploiting sediment at $34 \mathrm{~cm}$. This burrowing depth is attributed to the mobility of the chironomid, which permits it to ascend and descend to and from the oxygenated zone. Chironomid larvae also contain hemoglobin, which enables them to carry more oxygen to suboxic and anoxic depths. The animals were observed to swim in sediment, and a typical cycle observed in the laboratory aquarium was approximately 30 minutes. At depth, chironomid larvae consumed decomposing algae from the termini of Polykladichnus-like burrows or from the end of blind branches that constitute the Thalassinoides-like burrows. The general trophic level (eutrophic) of these larvae is remarked upon by Sæther (1979), who noted that many northerly chironomid species persist in waters rich in mineral and organic nutrients that promote a proliferation of plant life, particularly algae, which reduces the dissolved oxygen content and can cause the extinction of other organisms. In these settings, chironomid larvae feed on decomposing algae. The lower parts of the chironomid burrows likely represent deposit-feeding structures and temporary domiciles (Walsh, 1951; Sæther 1979). The deposit-feeding behavior takes place as subsurface mining, and the resulting burrow morphologies are comparable to chironomid larvae burrows presented in Charbonneau and Hare (1998). The upper part of the burrow is used to harvest oxygen from the photosynthetic layers in midwinter and provides access to oxygenated water in the summer months.

Vertical trace fossils are subordinate components of rock-record ichnocoenoses. The Mermia Ichnofacies, which is used to encapsulate

FIGURE 5-Microsensor profiles of (A) aqueous $\mathrm{H}_{2} \mathrm{~S}$ concentration, (B) $\mathrm{pH}$ as a function of sediment depth, and (C) oxygen partial pressure. Negative depth values represent readings taken in the water column immediately above the sediment-water interface. Profiles were obtained on four dates over the course of a single year to highlight seasonality of lake conditions. 
ichnological patterns in lacustrine settings, is dominated by horizontal trails of various morphologies and a small range of Repichnia (Buatois and Mangano, 2002; de Gibert et al., 2000). In all likelihood, the lower preservation potential of vertical trace fossils-especially those that lack heterolithic infill-is attributable to their emplacement in water-saturated bottom deposits. Similar, branching forms have been reported from temperate and glacial lakes. These are dominantly emplaced in organic-poor sandy silt, suggesting insect larval colonization of more cohesive sediment. Although the records of high-latitude lake deposits are few (e.g., Duck and McManus, 1997; Virtasalo et al. in press), it is apparent that temperate-to-high-latitude, freshwater ichnocoenoses may depart significantly from the archetypal Mermia Ichnofacies. Other departures from the Mermia Ichnofacies are presented in Hasiotis (2004; fig. 25A on p. 226) and Hasiotis (2005) in reporting of chironomid burrows with only the chimneys preserved, suggesting that the U-shaped (vertical part) tube had collapsed because it wasn't reinforced or used long-term.

\section{Geochemistry}

Our measurements indicate that $\mathrm{H}_{2} \mathrm{~S}$ concentrations increase with depth, $\mathrm{pH}$ decreases with depth (generally following $\mathrm{H}_{2} \mathrm{~S}$ ), and dissolved oxygen content is highest in the uppermost sediment (higher than the bottom water) and decreases markedly with depth. These results are intuitive; $\mathrm{H}_{2} \mathrm{~S}$ increases downward because oxygen is consumed, and in situ sulfate reduction becomes the viable microbial energy source. Acidity is either generated directly, by reaction 1 , or indirectly, as $\mathrm{H}_{2} \mathrm{~S}$ dissociates to $\mathrm{H}^{+}$and $\mathrm{HS}^{-}$by reaction 3 (below). Oxygen levels are a direct manifestation of algal and cyanobacterial activity.

$$
\begin{aligned}
2 \mathrm{CH}_{2} \mathrm{O}+2 \mathrm{O}_{2} & \Leftrightarrow 2 \mathrm{HCO}_{3}{ }^{-}+2 \mathrm{H}^{+} \\
2 \mathrm{CH}_{2} \mathrm{O}+\mathrm{SO}_{4}{ }^{2-} & \Leftrightarrow 2 \mathrm{HCO}_{3}{ }^{-}+\mathrm{H}_{2} \mathrm{~S} \\
\mathrm{H}_{2} \mathrm{~S} & \Leftrightarrow \mathrm{HS}^{-}+\mathrm{H}^{+}
\end{aligned}
$$

Sulfur cycling involves reductive and oxidative processes (Jorgensen, 1990). Sulfate is derived from the lake water, while hydrogen sulfide is produced via bacterial sulfate reduction. Hydrogen sulfide is then converted to organic sulfur or pyrite, or it is oxidized back to sulfate through biological and chemical means (Jorgensen, 1988). The most important factors controlling the rate of sulfate reduction are the concentration of sulfate, the amount of reactive organic carbon, and the presence of oxygen (Westrich and Berner, 1984; Holmer and Storkholm, 2001). High concentrations of sulfate under low $\mathrm{O}_{2}$ levels stimulate reduction. The increasing concentrations of $\mathrm{H}_{2} \mathrm{~S}$ with depth in the sediment and increasing $\mathrm{H}_{2} \mathrm{~S}$ in the water column over the winter months hallmark lower oxygen levels, not higher sulfate availability. With increasing $\mathrm{pH}, \mathrm{H}_{2} \mathrm{~S}$ dissociates to $\mathrm{HS}^{-}$and $\mathrm{H}^{+}$. At $\mathrm{pH} \sim 7,\left[\mathrm{H}_{2} \mathrm{~S}\right]$ equals $\left[\mathrm{HS}^{-}\right]$. Below $\mathrm{pH}$ $7, \mathrm{H}_{2} \mathrm{~S}$ is the dominant species, whereas above $\mathrm{pH} 7, \mathrm{HS}^{-}$and $\mathrm{H}^{+}$are dominant. Lower $\mathrm{pH}$ values at Cooking Lake (Fig. 5B) correspond to the parts of the sediment where the oxidation of sulfide paired to the reduction of oxygen is taking place, which generally corresponds to detectable oxygen levels in the sediment.

Dissolved oxygen content in the sediment decreases throughout the year because photosynthetic $\mathrm{O}_{2}$ production drops markedly after ice seals the lake, and the rates of photosynthesis decline. By contrast, in this study, in the late summer, $\mathrm{O}_{2}$ concentrations were very high in the bottom water and at the top of the organic-rich sediment (155\% atm), reflecting high surface irradiation and greater oxygenic photosynthetic activity. By December, after about 70 days of ice cover, dissolved oxygen was $30 \%$ atm. With ice covering, the lake entered an $\mathrm{O}_{2}$ deficit, where dissolved oxygen was being consumed faster than it was produced. Oxygen commonly can become so low that it causes mass mortality in the fish fauna; the conditions of winterkill and winter-lake anoxia are accounted for in Greenbank (1945). February displayed highly anoxic waters that permitted the diffusion of $\mathrm{H}_{2} \mathrm{~S}$ into the water column. So in February, the only local source of $\mathrm{O}_{2}$ was a thin layer near the sediment-water interface where photosynthesis still occurred; the second peak revealed the probe intersection with a chironomid larva. We suggest that the $\mathrm{O}_{2}$ concentration is higher in the chironomid than in the photosynthesizing zone because transport back to the lab permitted some gas diffusion from the sediment-water interface before the probe could be inserted into the sediment. The oxygen produced diffuses into the surrounding media and is consumed by aerobes or through the oxidation of $\mathrm{H}_{2} \mathrm{~S}$. April was characterized by continued $\mathrm{O}_{2}$ impoverishment of the sediment but a return of bottom-water $\mathrm{O}_{2}$ delivered from runoff entering the lake margins.

In spite of highly dynamic geochemical conditions in the sediment of Cooking Lake, our observations show that the activities of chironomid larvae are unperturbed. This was contrary to our initial expectations. It is especially surprising that chironomids can continue in their activities in conditions where the bottom water contains no oxygen. In fact, chironomids are exhibiting a behavior not previously considered by ichnologists: the harvesting of locally produced oxygen concentrated in a photosynthetic zone. We recognize, however, that the chironomid burrows do have a dual purpose; food collection occurs at the burrow terminus, and oxygen extraction near the sediment-water interface. It is evident that the larvae descend as much as $34 \mathrm{~cm}$ depths to feed and return to the photosynthetic factory to breath. They are able to do this in the direst of conditions, providing that the photosynthetic zone produces $\mathrm{O}_{2}$ at a rate that slightly exceeds diffusion (i.e., to maintain a zone of higher $\mathrm{O}_{2}$ concentration). This behavior is enhanced, and perhaps enabled, by the presence of hemoglobin in some types of chironomid larvae, which allows the animal better use of $\mathrm{O}_{2}$ resources. For example, Sæther (1979) showed that in temperate Canadian lakes (e.g., Lake Winnipeg), Chironomus plumosus and $C$. decorus, which are both hemoglobin bearing, are consistently associated with eutrophic and extreme eutrophic conditions. In other words, Chironomids possess excellent behavioral and functional adaptations that permit them to exploit lakes prone to seasonal eutrophy.

\section{CONCLUSIONS}

This paper presents observations and in situ geochemical measurements of chironomid larvae in their habitat. Despite colonizing soft, water-saturated, and organic-rich sediment, the larvae are still capable of maintaining open burrows. The burrows were generally small and Y-shaped (e.g., Polykladichnus-like), or Y-shaped with basal branches (e.g., Thalassinoides-like). The burrowing larvae were observed commonly to a depth of $20 \mathrm{~cm}$. The animal was seen to swim in the sediment up and down from the oxygenated zone. At depth, the chironomid larvae consumed decomposing algae from the termini of Y-shaped burrows or from the end of blind branches that constituted the branched burrows. In general, the trace assemblage does not conform to examples of the Mermia Ichnofacies, nor does it conform to the reports of modern ichnocoenoses in low-latitude water bodies like Lake Tanganyika (Hasiotis et al., 2005) or Late Jurassic lake deposits of the Morrison Formation (Hasiotis, 2004).

Chironomid burrows represent deposit-feeding structures and temporary domiciles. In winter, the chironomid larvae harvest their oxygen from the uppermost photosynthetic layer in otherwise $\mathrm{O}_{2}$ impoverished sediments. So the burrows are, in part, an oxygen-mining structure.

With respect to the pore-water geochemistry, $\mathrm{H}_{2} \mathrm{~S}$ concentrations increase with depth, $\mathrm{pH}$ decreases with depth (generally following $\mathrm{H}_{2} \mathrm{~S}$ ), and dissolved oxygen content decreases with depth. The same trends occur with winter eutrophy. All of the geochemical trends can be explained through known models of sulfate cycling. Burrowing behavior in this study was not linked to geochemical trends but instead reflected the ability of chronomid larvae to exploit oxygen oases in the sediment. The oxygenated oases were only present at the sediment-water interface where photosynthesis contiuously produced $\mathrm{O}_{2}$ despite the rapid (microbial) consumption of $\mathrm{O}_{2}$ away from in the water column and within the sediment. 


\section{ACKNOWLEDGMENTS}

Research was made possible through the provision of Discovery Grants to M.K.G. and K.O.K. from the Natural Science and Engineering Research Council of Canada. Drs. Heather Proctor and Doug Craig provided taxonomic evaluations and insights into chironomid larvae. Thank you to Dr. S. George Pemberton for ichnological insights. Drs. Molly Miller and Luis Buatois reviewed this paper, and their comments improved the reporting of the study significantly. Finally, thank you to Scott Botterill who looked after the lab animals by faithfully changing the aquaria waters, and to Dr. Alex Wolfe for the use of his coring equipment.

\section{REFERENCES}

Andersen, F.E., and Jensen, H.S., 1991, The influence of chironomids on decomposition of organic matter and nutrient exchange in a lake sediment: Verhandlungen der internationale Vereinigung für Theoretische und Angewandte Limnologie, v. 24 , p. 3,051-3,055

Berner, R.A., and Westrich, J.T., 1985, Bioturbation and the early diagenesis of carbon and sulphur: American Journal of Science, v. 285, p. 193-206.

Boudreau, B.P., and Marinelli, R.L., 1994, A modelling study of discontinuous biological irrigation: Journal of Marine Research, v. 52, p. 947-968.

Brinkhurst, R.O., 1974, The Benthos of Lakes: Macmillan Press, London, 182 p.

Buatois, L.A., and Mangano, M.G., 2002, Trace fossil analysis of lacustrine facies and basins: Palaeogeography, Palaeoclimatology, Palaeoecology, v. 140 , p. $367-$ 382.

Charbonneau, P., and Hare, L., 1998, Burrowing behavior and biogenic structures of mud-dwelling insects: Journal of the North American Benthological Society, v. 17, p. 239-249.

Covich, A.P., Palmer, M.A., and Crowl, T.A., 1999, The role of benthic invertebrate species in freshwater ecosystems: BioScience, v. 49, p. 119-127.

de Gibert, J.M., Fregenal-Martinez, M.A., Buatois, L.A., and Mangano, M.G., 2000, Trace fossils and their palaeoecological significance in Lower Cretaceous lacustrine conservation deposits, El Montsec, Spain: Palaeogeography, Palaeoclimatology, Palaeoecology, v. 156, p. 89-101.

Duck, R.W., and McManus, J., 1997, Chironomid larvae trails in proglacial lake sediments: Reply: Boreas, 16, 322

Fukuhara, K., and SaKamoto, M., 1987, Enhancement of inorganic nitrogen and phosphorus release from lake sediment by tubificid worms and chironomid larvae: Oikos, v. 48, p. 312-330.

GLEw, J., 1989, A new trigger mechanism for sediment samplers, Journal of Paleolimnology, v. 2(4), p. 241-243.

Graneali, W., 1979, The influence of Chironomus plumosus larvae on the oxygen uptake of sediment: Archiv für Hydrobiologie, v. 87, p. 385-403.

GreEnBANK, J., 1945, Limnological conditions in ice-covered lakes, especially as related to winter-kill of fish: Ecological Monographs, v. 15, p. 343-392.

Hansen, K., Mouridsen, S., and Kristensen, E., 1998, The impact of Chironomus plumosus larvae on organic matter decay and nutrient $(\mathrm{N}, \mathrm{P})$ exchange in a shallow eutrophic lake sediment following a phytoplankton sedimentation: Hydrobiologia, v. 364 , p. $65-74$

Hasiotis, S.T., 2004, Reconnaissance of Upper Jurassic Morrison Formation ichnofossils, Rocky Mountain region, USA: Environmental, stratigraphic, and climatic significance of terrestrial and freshwater ichnocoenoses: Sedimentary Geology, v. 167, p. 277-368.

Hasiotis, S.T., 2005, Using ichnofossils and ichnocoenoses to interpret paleoenvironmental and paleoecological settings of the Upper Jurassic Morrison Formation,
Western Interior Basin, USA: Abstracts with Programs, Geological Society of America, v. 37, p. 13.

Hasiotis, S.T., Kennedy, D., Todd, J.A., and Michael, E., 2005, Preliminary report on modern organism traces from the supralittoral to sublittoral zone in Kigoma Bay, Lake Tanganyika, Tanzania: American Association of Petroleum Geologists Annual Meeting, Nonmarine Depositional Systems II, Calgary, Alberta, Canada, $1 \mathrm{p}$.

Hofmann, W., 1971, Zur Taxonomie und Paloekologie ubfossiler Chironomiden (Dipt.) in Seesedimenten: Archiv für Hydrobiologie Beihefte Ergebnisse der Limnologie, v. 6, p. 1-50.

Hofmann, W., 1986, Chironomid analysis, in Berglund, B.E., ed., Handbook of Holocene Palaeoecology and Palaeohydrology: J. Wiley \& Sons, Chichester, England, p. 715-727.

Holmer, M., and Storkholm, P., 2001, Sulphate reduction and sulphur cycling in lake sediments: A review: Freshwater Biology, v. 46, p. 431-451.

Jorgensen, B.B., 1988, Ecology of the sulphur cycle: Oxidative pathways in the sediment, in Cole, J.A., and Ferguson, S.J., eds., The Nitrogen and Sulphur Cycles: Cambridge University Press, Cambridge, p. 31-63.

Jorgensen, B.B., 1990, The sulfur cycle of freshwater sediments: Role of thiosulfate: Limnology and Oceanography, v. 35, p. 1,329-1,342.

Miller, M.F., 1984, Distribution of biogenic structures in Paleozoic nonmarine and marine-margin sequences: An actualistic model: Journal of Paleontology, v. 58, p. $550-570$.

Mitchell, P., and Prepas, E.E., 1990, Atlas of Alberta Lakes: University of Alberta Press, Edmonton, 675 p.

SæтнеR, O.A., 1979, Chironomid communities as water quality indicators: Holarctic Ecology, v. 2, p. 65-74.

SæтнеR, O.A., 2000, Zoogeographical patterns in Chironomidae (Diptera): Verhandlungen der Internationalen Vereinigung für Theoretische und Angewandte Limnologie, v. 27, p. 290-302.

Svenson, J.M., and LeONARDSOn, L., 1996, Effects of bioturbation by tube-dwelling chironomid larvae on oxygen uptake and denitrification in eutrophic lake sediments: Freshwater Biology, v. 35, p. 289-300.

Velle, G., Brooks, S.J., Birks, H.J.B., and Willassen, E., 2005, Chironomids as a tool for inferring Holocene climate: An assessment based on six sites in southern Scandinavia: Quaternary Science Reviews, v. 24, p. 1,429-1,462.

Virtasalo, J.J., Kotilainen, A.T., and Gingras, M.K., 2006, Trace fossils as indicators of environmental change in Holocene sediments of the Archipelago Sea, northern Baltic Sea: Palaeogeography, Palaeoclimatology, Palaeoecology, v. 240, p. 453-467.

WALKER, I.R., 1987, Chironomidae (Diptera) in paleoecology: Quaternary Science Review, v. 6, p. 29-40.

WALKER, I.R., 1995, Chironomids as indicators of past environmental change, in Armitage, P.D., Cranston, P.S., and Pinder, L.C.V., eds., The Chironomidae: Biology and Ecology of Non-biting Midges: Chapman \& Hall, London, p. 405-422.

WaLsh, B.M., 1951, The feeding habits of certain Chironomid larvae (subfamily Tendipedinae): Proceedings of the Zoological Society of London, v. 121, p. 6379.

Warwick, W.F., 1980, Palaeolimnology of the Bay of Quinte, Lake Ontario: 2800 years of cultural influence: Canadian Bulletin of Fisheries and Aquatic Sciences, v. 206 , p. 1-117.

Westrich, J.T., and Berner, R.A., 1984, The role of sedimentary organic matter in bacterial sulphate reduction: The $G$ model tested: Limnology and Oceanography, v. 29 , p. $236-249$.

ACCEPTED OCTOBER 1, 2006 